\title{
The illegal trade in black caviar
}

\author{
Daan van Uhm ${ }^{1} \cdot$ Dina Siegel $^{1}$
}

Published online: 24 February 2016

C The Author(s) 2016. This article is published with open access at Springerlink.com

\begin{abstract}
The trade in caviar has a rich and colorful history, influenced over thousands of years by many cultures, societies and in the last decades by regulation. The value of caviar is historically discovered in the context of social change, political relationships and environmental change. The role of organized crime is described, as the scarcity of caviar has offered the unique opportunity to fish illegally, smuggle and trade contraband to mainly European countries with millions in profits. This study highlights that these criminal networks manifest themselves at all levels of the trade: from the poaching areas where organized criminal groups cooperate with law enforcers and possess top-notch equipment to major smuggling operations in the hands of sophisticated criminal networks. Although due to overexploitation 'wild caviar' is increasingly difficult to obtain, the demand in the context of exclusivity and scarcity remains intact by the upper class society desire for edible gold.
\end{abstract}

Keywords Illegal caviar trade · Organized crime · Green criminology · Wildlife trade · CITES

\section{Introduction}

'Today there is no legal Russian caviar in Europe', 'Caviar without rules', 'Black caviar will disappear, but only for the poor and the honest'3; 'There will never be black caviar again, ever'. These were some of the headlines regarding

\footnotetext{
${ }^{1}$ Izvestia, 25 December, 2003.

${ }^{2}$ Izvestia, 26 March, 2004.

${ }^{3}$ Pravda, 5 January, 2006.

${ }^{4}$ Izvestia, 31 October, 2006.
}

Daan van Uhm

d.p.vanuhm@uu.nl

Dina Siegel

d.siegel@uu.nl

1 Willem Pompe Institute for Criminal Law and Criminology, Utrecht University, Utrecht, The Netherlands 
illegal sturgeon fishing in Russia and illegal caviar exports to Europe that appeared in Russian newspapers over the past ten years. There are suspicions that 90 percent of the caviar currently being sold is extracted from illegally caught sturgeon (Nelleman et al. 2014). Prices in Western Europe range from 2000 or 6000 euros per kilo, to sometimes 25000 euros per kilo for extremely rare varieties (Liddick 2011: 77-78; Neve et al. 2012: 34). Some authors suggest that a mysterious and violent so-called 'caviar mafia' make huge profits from this illegal trade (e.g. Sellar 2014).

For a long time, criminologists paid little attention to environmental crimes. This slowly changed in the 1990s and 2000s when several criminologists started to study green crimes, including wildlife-related crimes. On the one hand, criminologists approached the wildlife trade by applying an extended harm-based model (e.g. Wyatt 2013; Sollund 2013). Due to the fact that definitions of crime may alter over the course of time in the context of changing norms and morals, these criminologists suggest that wildlife crimes and harms that are not (yet) criminalized by law should be studied. Besides (social) anthropocentric harms (e.g. Hillyard et al. 2004), green criminologists extend the harm principle with species and ecosystems as victims of (human) actions in general and the symbiosis between man and nature in particular (South 1998; White 2008, 2011).

On the other hand, criminologists have focussed on the wildlife trade by approaching it from environmental criminological models (e.g. Pires and Moreto 2011; Petrossian and Clarke 2014). These frameworks originate from criminologists (e.g. Clarke 1983) who argue that crime is influenced by environmental factors. Situational circumstances can offer opportunities or limitations for committing crimes. From this perspective the focus is on the event in order to understand and explain the crime, but also items are attractive to be stolen for their enjoyable, valuable and concealable features (Moreto and Lemieux 2014).

The present study answers the call for empirical research on wildlife crimes as insights into this type of crime are extremely limited and only very few criminological studies have focussed on this research field. This study aims to contribute to criminological research on wildlife crimes by exploring the illegal trade in caviar as one specific case study from a research project on the illegal wildlife trade that started in 2012. ${ }^{5}$ Given the exploratory objectives of the present study, the primary data was collected and used from a grounded theory approach. This is an inductive and iterative strategy that results in the construction of theories or concepts from 'within the data themselves' (Charmaz 2006: $2)$. The purpose of this study is twofold: firstly, to analyse how criminal networks operate along the whole 'pipeline' of the illegal trade in caviar and, secondly, to consider what the social, economic and environmental contexts and consequences of their activities are. This study thereby contributes to both criminological and conservation science literature and provides a basis for future research on wildlife crimes. The article starts with a brief overview of the social construction of the value of caviar and regulation and criminalization issues.

\footnotetext{
5 The research results are part of the doctoral research 'Uncovering the illegal wildlife trade: inside the world of poachers, smugglers and traders' by Daan van Uhm at Utrecht University.
} 
Then the main findings of our study will be presented and the article will be concluded with a discussion.

\section{Caviar in Russia - the short history of a luxury product}

'Myths are one of the key ingredients in caviar. Stripped of its shroud of legend and tradition, caviar would just be fish eggs' (Saffron 2002: 152)

Sturgeon have been around for some 250 million years and their eggs were appreciated and consumed in many ancient cultures (Shadrina 2007; Nikolaev et al. 2009). Around 2400 B.C., the ancient Egyptians and Phoenicians prepared sturgeon eggs with salt and vinegar. According to Aristotle, the Greeks were also no strangers to caviar: they served it on platters garnished with flowers (Gordon 2003). Many centuries later, the Russian tsars imposed a caviar tax on fishing for sturgeon, which may have formed the basis for the exclusivity of caviar.

According to Georg Simmel, the value of an object is not an inherent quality, but a valuation of the object (Simmel 1978: 72-73). The value will increase as the meaning of the object in a certain social context increases. During various historical periods this has happened with, for instance, sugar, tea and diamonds. In his work on the development of the sugar industry, Mintz (1985) showed how Europeans transformed sugar from an exotic luxury product to a daily necessity. Tea was originally considered as a luxury product for the wealthy elite, but in a relatively short period of time drinking tea was adopted by the lower classes, who began to copy the fashions of the upper classes. The creation of the value of diamonds took a new direction when, besides socio-economic processes, political factors began to play a role, such as in the case of blood diamonds. Against the background of violent conflicts in Angola and Sierra Leone, the diamond, a symbol of love, has also become a symbol of war and misery (Siegel 2009).

Luxury goods can become status symbols for the elite, but they can also manifest themselves as 'national symbols': in our time, caviar - along with vodka and matryoshka dolls - is seen as a typically Russian product. But how are symbols created and by whom? Why is it that caviar has attained the status of 'edible gold'?

In the Middle Ages, caviar became a popular dish in Russia, because fish and fish products were allowed on the days when it was forbidden for Russian Orthodox Christians to eat meat (Saffron 2002: 47-53). The Russian word for caviar is ikra (икра), which literally means fish roe. In Judaism and Islam, on the other hand, caviar is considered unclean. ${ }^{6}$ In the days of Ivan the Terrible (1530-1584), fishermen supplied sturgeon to the court of the tsar, where caviar was served at receptions for foreign diplomats. Peter the Great (1672-1725) established a 'Fishery Head Office' in Astrakhan and made it responsible for the delivery of so-called 'troitshnaya' caviar, i.e. caviar transported to St. Petersburg by troika (a sled drawn by three horses) within three

\footnotetext{
${ }^{6}$ This changed in 1981 when Ayatollah Khomeini announced that caviar was halal, perhaps in order to bolster Iran's competitive position on the world market against Russia. Many Iranians still avoid eating caviar (Saffron 2002:137).
} 
days. At the same time, caviar was considered a dish for the poor. In the 17th century, it was sold cheaply in the markets and taverns of towns and cities all over Russia.

For a long time, sturgeon fishing in Russia was controlled by the Don and Volga Cossacks. There is no consensus among historians and anthropologists on who the Cossacks really were: whether they were a nation, a subsection of a tribe, or a caste of warriors. What the experts do agree upon is that relations between the Cossacks and the Russian tsars have always been complicated. In the 17th and 18th century, the Cossacks became associated with criminality. Some of their atamani (leaders) were not only known as bandits, but also as pirates, such as the legendary Stepan Razin (Siegel 2005: 48-49).

Although European traders first came across caviar around the 14th century, it took some time for the product to attain 'luxury status'. The Europe-oriented tsar Peter the Great encouraged the production of caviar and allowed the Cossacks to secure an exclusive position in the sturgeon fishing industry. In the 18th century Russia began to attract foreign investors. One of the important figures in the history of caviar was Ioannis Varvakis, a Greek sea captain and trader who 'discovered' Russian caviar around 1780 and subsequently began to promote the consumption of caviar to the European upper classes (Saffron 2002). His trade marked the beginning of a process of transformation, as a result of which sturgeon eggs were no longer regarded as peasant food, but came to be seen as a globally recognised symbol of wealth and power.

Two important developments have contributed to the popularity of caviar: the Industrial Revolution with its improvements in transportation and the emergence of a new class of consumers willing to pay good money for new exotic products. At the beginning of the 20th century, only wealthy Russians could afford to eat caviar (ibid: 76), while in Europe eating caviar became a trend among the nouveaux riches of the Belle Époque, alongside champagne and oysters. This was a drastic change compared to the 19th century, when Russian farmers fed caviar to their pigs or threw it out with the garbage.

During the First World War, after the Bolshevik Revolution of 1917, the Communist regime took over the Caspian fishing industry. Sturgeon catches in the open sea were strictly prohibited by the Soviets (Vaisman 1997; Ruban and Khodorevskaya 2010). The Soviet Union ended up controlling $90 \%$ of the world production of caviar. Foreign entrepreneurs were not allowed near the caviar fishing industry (Saffron 2002: 114).

This total control over caviar production guaranteed the value of the product. At the same time, caviar was the food of the nomenklatura and a lucrative black market emerged. In Soviet times, corruption and the abuse of power were regarded as inevitable consequences of the socialist economy and the lines between legal and illegal were often blurred (Siegel 2005: 63). According to the Russian sociologist Konstantin Simis, Soviet citizens needed two things to survive in the Soviet system: money and connections to the underground business world (Simis 1982). 'Caviar became an underground currency, a luxurious way of greasing palms and extracting favors' (Saffron 2002: 116). The positive side of the Soviet monopoly was that the fishery was closely monitored: with an eye on a balanced population, sturgeon fishing was outlawed in the Caspian Sea as early as 1962.

The Soviet authorities guarded the production of caviar in a way which was comparable to how De Beers protected its diamond mines. Production was centralised 
under a highly efficient state monopoly. However, after the fall of communism the caviar trade was privatised. In the first years after the economic reforms, sturgeon was overfished and caviar was exported in large quantities. Under pressure from environmental groups steps were finally taken to regulate the fishery and fishing companies were issued with licences.

\section{Regulation and criminalization}

The dissolution of the Soviet Union in the early 1990s led to the collapse of existing management and control systems, the subsequent overexploitation of wild sturgeon stocks, and the involvement of criminal networks (De Meulenaer and Raymakers 1996; Birstein et al. 1997; Raymakers 2002). Since 1998, the caviar trade has been regulated under CITES, the Convention on International Trade in Endangered Species, to combat unsustainable harvesting and illegal trade. Currently, the international trade in sturgeon and sturgeon products, such as eggs for caviar, is only allowed when shipments are accompanied by the appropriate import and export certificates (Oldfield 2003; European Commission 2010).

CITES is signed by 181 countries, including the countries around the Caspian Sea: Russia, Kazakhstan, Iran and Azerbaijan (with the exception of Turkmenistan), and implemented by the European Union in a joint regulation that applies to all EU member states. ${ }^{7}$ All international shipments of caviar must be accompanied by CITES permits, with the exception of a maximum amount of $125 \mathrm{~g}$ of caviar per person to be used for non-commercial purposes (CITES II/appendix B sturgeons). ${ }^{8}$ Caviar containers are required to bear non-reusable labels ${ }^{9}$ and the caviar must be packaged in such a way as to permit visual evidence of any opening of the container. As of 2006, the EU has mandated that not only the original packaging, but also repackaged caviar must be affixed with a non-reusable label. Repackaging companies must be registered with the CITES authorities. ${ }^{10}$

Due to large amounts of illegal catches and the decline in sturgeon populations, CITES proposed an export ban on caviar for the countries around the Caspian Sea in 2001. Subsequently, Russia, Azerbaijan and Kazakhstan committed themselves to a range of measures, including export quotas to reduce overfishing (Raymakers 2002). Since 2007 when the sturgeon population had declined significantly, Russia completely banned wild sturgeon harvesting under the pressure of different international organizations. This ban was joined by all Caspian littoral states in 2014 (Nellemann et al. 2014) and has led to the further criminalization of sturgeon catches.

\footnotetext{
7 This EU regulation consists of EC regulations regarding the trade in species of wild fauna and flora (Council Regulation (EC) no. 338/1997), and the related Commission Regulation (EC) no. 865/2006). The regulation determines the conditions under which protected species, such as sturgeon (and sturgeon products), may be traded and the documents that are required.

${ }^{8}$ Conf. 13.7 (Rev. CoP14).

${ }^{9}$ The label should include the following information: species, captive-bred or harvested from the wild, the country of origin, the year of harvest, the registration code of the processing plant and a lot identification number.

${ }^{10}$ Commission Regulation (EC) no 865/2006.
} 
In Russia, the punishment for the illegal fishing of sturgeons is a fine of up to 500,000 roubles or three years imprisonment, including the seizure of equipment and vehicles used during poaching and compensation for the damage to the species (Maltsev 2009). In different EU member states the maximum punishments for the illegal trade in caviar vary from a fine of several thousand euros to years of imprisonment (Traffic 2014). Despite such regulations and measures the sturgeon population in the Caspian Sea has decreased dramatically. Due to the overexploitation of sturgeon for the caviar industry, $85 \%$ of the sturgeon species are now threatened with extinction in comparison to $44 \%$ in 1996 (Bronzi and Rozenthal 2014). At the same time the value of caviar increased disproportionately to thousands of euros per kilo because of the declining sturgeon populations and various criminal groups became involved in the illegal trade in this pre-historic fish.

\section{Methodology}

In the course of this case study on caviar the primary data was collected and used from a grounded theory approach whereby theory or concepts are constructed through the analysis of data (Charmaz 2006: 2). Given the exploratory focus of the study, qualitative methods were used to obtain in-depth knowledge of the illegal caviar trade, while the multi-site nature of the study afforded the authors to utilize the same research plan at various local, regional, national, and international sites (Siegel 2009). According to Marcus (1995) during the multi-sited research one follows the people, the thing, the story, the biography, the metaphor or the conflict, in this case - the illegal trade in caviar along its route.

The primary fieldwork took place in March, September and October 2014 based on semi-structured interviews with local people involved in the illegal trade in the main source countries of Russia, Kazakhstan and Azerbaijan and in the European Union as destination market. Semi-structured interviews allow specific issues to be addressed in more detail, including examples and the informants' own experiences (Davies, Francis and Jupp 2011). A total of 67 informants in Russia, Kazakhstan and Azerbaijan were spoken, including poachers, illegal traders, smugglers and middlemen. Other informants include persons who are indirectly involved, such as legal traders, scientists, journalists, lawyers, officials and representatives of relevant organizations and institutions to compare the stories and interpretations of our primary informants. Respondents were collected through snowball sampling; future participants were recruited from among their acquaintances and through the first point of access (Goodman 1961).

During the fieldwork participant observation was carried out in the areas where sturgeon were being poached (e.g. Astrakhan delta, Lagan, Sulak, Atyrau, Neftçala) or in the trading areas (e.g. Moscow, Makhachkala, Astrakhan, Baku). By observing the process of the illegal trade, through direct, naturalistic observations, it was possible to gain a more in-depth understanding of the general context in which actors operate (DeWalt and DeWalt 2011). Both obtrusive and unobtrusive methods were used depending on the setting. In a covert setting this could be an advantage as people would not be aware that they are being observed by a researcher (Zaitch, Mortelmans and Decorte 2009). For instance, at several markets traders sold their illegal caviar under the counter (unobtrusive). On the other hand, more overt (obtrusive) methods 
were used to get in touch with key persons in the illegal caviar trade. This resulted in a continuum between both insider and outsider experiences (Spradley 1980). This varied from a detached observer to a participant observer with social relationships with informants.

In order to corroborate and triangulate the qualitative data, we also collected secondary data on confiscations in the EU. These data have been obtained from the European Union Trade in Wildlife Information eXchange database (EU-TWIX), the database on wildlife seizures in the EU (see also Van Uhm 2016). The data includes more than 1500 illegal shipments $(N=1585)$ of caviar confiscated in the EU between 2001 and 2010. The data were organized into a categorical SPSS ${ }^{11}$ database and descriptive statistics were used to analyse the seizures. The confiscations, however, only reflect a part of the illegal trade, because most of the trade is unreported or undiscovered, the so-called dark number (Coleman and Moynihan 1996). It has been estimated that no more than $10 \%$ of all wildlife contraband is seized (Stiles et al. 2013). Both qualitative and quantitative research methods have been used to uncover the mechanisms behind the illegal caviar trade. These data triangulation and methodological triangulation made it possible to compare the information from the different sources with each other for verification and to increase the internal validity and reliability of the research.

Several reports from international organizations such as CITES and the Wildlife Trade Monitoring Network (TRAFFIC) provided also valuable data. Due to the availability of only a few criminological studies on illegal fisheries in general and sturgeons specifically, literature from other disciplines (e.g. environmental law, conservation biology) has been used (e.g. Pikitch et al. 2005; Nikolaev et al. 2009).

\section{Findings}

\section{Criminal networks around the Caspian sea}

The Caspian Sea is bordered by five nations: Azerbaijan, the Russian Federation, Kazakhstan, Turkmenistan and Iran. Russia and Iran are still the largest caviar producers, but in the 2000s the other countries developed into strong competitors. Within the Russian Federation three republics are competing with each other: Kalmykia, Dagestan and Russia. For the Caucasus, especially the Republics of Dagestan, Chechnya, and Ingushetia, a decline in living conditions, a lack of social guarantees, and social polarization became the main causes of the economic criminalization (Cheloukhine and Haberfeld 2011: 107). In Soviet times, almost 70 \% of Dagestan's industry consisted of the catching and processing of fish. As a result of the collapse of the socialist market many workers and fishing experts found themselves unemployed. Due to these socio-political changes, these ordinary people often resort to poaching. ${ }^{12}$ They have no other way of feeding their families (Vaisman 1997; Raymakers 2002;

\footnotetext{
${ }^{11}$ SPSS: Statistical Package for the Social Sciences.

${ }^{12}$ In Azerbaijan the oil fields turned out to be depleted and caviar became the main source of foreign currency after the dissolution of the Soviet Union (Glenny 2008: 75).
} 
Ruban and Khodorevskaya 2010). As described by one of the poachers interviewed, "People are very poor in the Astrakhan delta, Lagan and Dagestan. They are scared, because the police can send you to jail, but if you catch one [a big sturgeon with eggs] you have made a living for years." 13 Based on observations, indeed, the fishermen around the Caspian Sea live in poor villages in small barracks in areas without paved roads which are sometimes only accessible by boat (e.g. Kirovskiy; Poldnevoye; Lagan; Sulak; Neftçala).

Such remote areas are known in criminology as the most vulnerable places for the activities of criminal organisations (Bovenkerk 2001: 138-144). Organized crime is always strong in weak states and in regions where the government has not succeeded in using the effective monopoly of violence (ibid: 138). Such remote and economically underdeveloped places have always been territories for banditry and piracy. The regions around the Caspian Sea are not an exception.

In the 1990s the caviar trade became extremely profitable. Not just legitimate businesspeople, but especially brakonieri (poachers) started to fish for sturgeon on a massive scale and enormous amounts of cheap caviar appeared on the Russian market. This resulted in a decrease in the price of caviar, which in turn led to an increase in demand - from outside the production countries - from around 300 to 450-500 t per year. In this way, cheaper caviar (instead of top quality) became available to the 'ordinary citizen' (Taylor 1997: 45). According to a middleman in Atyrau: "In the 1990s the sturgeon industry exploded and at that time very large numbers of sturgeons were available at the [black] market". ${ }^{14}$ At the end of the $1990 \mathrm{~s}$, approximately $3500 \mathrm{t}$ of illegally caught sturgeon were transported to Moscow every year and, according to Taylor (1997), this happened under the protection of Chechen organized crime. Caviar became even a sought after commodity in barter transactions (Knapp et al. 2006). A German firm in Kazakhstan, for instance, signed a contract to build 40 houses in exchange for $24 \mathrm{t}$ of caviar. In Astrakhan, promises were made to construct roads in exchange for caviar, but the caviar ended up in Alaska and no roads were ever built (Taylor 1997: 48). Since the 1990s entire coastal communities around the Caspian Sea have become involved in illegal sturgeon fishing and the production of caviar.

In 2014 the illegal market is well-organized; its participants arrange for sales channels, transport, and bribes to be paid along the way (to the traffic police and customs officers). Senior government officials, fishery inspectors, police services and other agencies all have a stake in the business. Given that the 'income' of local police and fish inspectors in bribes would be around 800 USD per motorboat and the wages are relatively low (Nelleman et al. 2014), the temptation is always there to accept bribes. This is demonstrated by the following quote from a police official in Makhachkala: "I am famous for being a fascist, because I do not take bribes (...) Most officials are corrupt in this region." 15 Low wages lead to high levels of corruption. A poacher in the Babayurt area of Dagestan illustrates the mutual benefits in their symbiotic relationships with officials: "We poach in groups of four people and work together with the police and inspectors. They know what is going on and of course we

\footnotetext{
${ }^{13}$ Personal communication, 22 March 2014, Lagan.

14 Personal communication, 19 March 2014, Atyrau.

${ }^{15}$ Personal communication, 23 September 2014, Makhachkala.
} 
pay them an amount of money to poach on sturgeon." 16 There are sometimes entire detailed agreements between the poachers and the water police. As described by one of the poachers interviewed in Babayurt, "We mark our boat with a sign so that they see during a helicopter control that we paid some bribes. Then they do not control the boat". 17 According to Passas (2002) the upper- and underworld are regularly intertwined in criminal networks. These examples demonstrate how the symbiotic interests of criminal networks and the police come together.

While in the early 2000s poachers used old Vikhr boats, these days the criminal networks are well-organized and use 'state of the art' means of transport. ${ }^{18}$ People borrow money to buy a Baida (a super light boat) worth 10 to 15000 USD and install two Japanese engines worth 30,000 USD. The poachers also acquire a 'Garmin', a navigation system worth 200 to 500 USD and fishing gear. One illegal catch brings around 170,000 roubles (USD 5000) in pure profit (Nelleman et al. 2014). The caviar is then transported from the fishing villages in plastic boxes, milk churns, thermos flasks and three-litre jars. According to a smuggler they smuggle caviar in small batches of 5 to $6 \mathrm{k}$ or large quantities of $40 \mathrm{k}$, usually by car (e.g. under the floor of the car, under the seats, in compartments behind the bumper), ${ }^{19}$ but around the holidays (such as New Year; 23 February, the Day of the Red Army; and 8 March, Women's Day) caviar is brought in by couriers who travel by train. According to Zabyelina (2014) profits for smugglers moving the contraband from the Caspian coast to the federal centre could reach 200-3000 dollars. As described by traders at the Teplyy Stan and Dorogomilovsky markets in Moscow, every morning between six and seven o'clock a truck arrives at the back of the market with smuggled caviar. ${ }^{20}$ "They drive with four cars in a convoy. The front one is the scout, if the police are not bribed or able to be bribed, he warns the other three cars to take an alternative route to Moscow." 21 Besides cars and trains the criminal networks even use helicopters to transfer caviar from Kazakhstan to Russia explained a poacher. ${ }^{22}$ In the cities, these couriers are met by representatives of trading companies who distribute the caviar to fish markets, restaurants and private customers. This is how illegal caviar ends up in legal trade networks. $^{23}$

A large part of the illegal trade is reportedly controlled by Russian mafia or organized crime (e.g. Wyler and Sheikh 2013; Sellar 2014). Many informants underlined the involvement of the Russian mafia, as described by one of the middleman, "There is no law at the market, the Russian mafia dominate the trade". ${ }^{4}$ Poachers pay 'taxes' to criminals or police in order to gain access to the Caspian Sea (and to be left alone), and are forced to hand over a certain percentage depending on the size of the catch. The poachers are regularly protected by the militias of the republics, for instance when there are conflicts with the federal authorities. Criminal groups in Dagestan use

\footnotetext{
${ }^{16}$ Personal communication, 24 September 2014, Babayurt.

${ }^{17}$ Personal communication, 24 September 2014, Babayurt.

${ }^{18}$ Personal communication with a police official, 23 September 2014, Makhachkala.

${ }^{19}$ Personal communication, 28 March 2014, Moscow.

${ }^{20}$ Personal communication, 24-25 March 2014, Moscow.

${ }^{21}$ Personal communication, 26 September 2014, Sulak.

22 Personal communication, 19 March 2014, Atyrau.

${ }^{23}$ Personal communication with a middleman, 27 September 2014, Baku.

24 Personal communication, 16 March 2014, Astrakhan.
} 
'security vessels' to escort the poachers and to distract the police stated a middleman in Izberbash. ${ }^{25}$ The business of private protection, which did not emerge in the postreform Soviet Union - the Italian Mafia used it long before Russian organized crime is mainly embedded in the present market economy of the former Soviet Union. Russian organized crime, according to Volkov, 'may be seen as a response to a certain institution demand by the nascent market economy, namely, the need to protect property rights, a need not satisfied by public protection and enforcement agencies' (Volkov 2002: 18).

Most legal and illegal fishermen enjoy such protection or ' $k r y s h a$ ' (literally a 'roof'). Krysha is the name for various transitional forms of protection (Volkov 2002: 22). The protection industry in the post-Soviet republics ranged from militseiskaya krysha (protection by the police) to kriminalnaya krysha (protection by criminal organisations) (Varese 2001: 59-72). The krysha model played a major role in post-communist developments, especially in the integration of the criminal and the legal economy. It refers to protection against petty thieves, but also against competitors and 'amateur extortionists' (Siegel 2005). A poacher in Ракуша (Atyrau), explained the role of such protection: "The middle enforcers, captains and lawyers, they all have a powerful person from the mafia standing behind their back and taking care of them. (...) If we have sturgeons on my boat and the police arrive, I call a certain person from the local mafia to say that the police have arrived. I give the phone to the policeman, the policeman talks to the person and they tell police to calm down and then the police let me go." 26

This interrelationship between the police and the poachers has also resulted in conflicts between poachers, the water police and coast guards. For instance, in 1996 the fishing boat 'Kamilia' was intercepted by the coast guards in Dagestan during the transfer of poached sturgeon to two heavy Kamaz trucks. While the Coast Guard tried to stop this activity, corrupt water militias, armed with sub-machine guns, opened fire on the guards and the trucks - guarded by private militias - disappeared (Vaisman 1997). At the end of the 1990s conflicts between poachers and the fishery police led to a bomb explosion in an apartment building occupied by members of the fishery police in Kaspiysk, a town in Dagestan. Some 68 people, including women and children, lost their lives (Saffron 2002: 136-137). In the mid-2000s the militarisation continued and hand grenades were used to scare off coast guard patrol boats (Knapp et al. 2006). Local officials described the situation as an ongoing war with the caviar mafia. ${ }^{27}$ According to a poacher in Poldnevoye: "Some local poachers use hand grenades, also to bomb certain upriver places to get sturgeons to the surface. (...) Others have automatic firearms to protect themselves from being shot by the police". ${ }^{28}$ Such conflicts result in an increasing level of armament on both the side of the poachers and the police. Moreover, there are many dangers at sea because many rival organized crime groups try to monopolize this profitable market; apart from collisions, fishermen are sometimes kidnapped by criminal groups from Kazakhstan explained several informants. Criminogenic factors such as scarcity, the exorbitantly high price of caviar,

\footnotetext{
${ }^{25}$ Personal communication, 25 September 2014, Izberbash.

${ }^{26}$ Personal communication, 19 March 2014, Atyrau.

27 The Moscow Times, Saradzhyan, 18 April 2001.

${ }^{28}$ Personal communication, 16 March 2014, Poldnevoye.
} 
social instability and corruption in the countries of origin make this type of criminality extremely attractive for criminal groups.

\section{Western Europe as a major outlet}

Western Europe appears to be the largest importer of caviar, both in terms of quantity and value (Engler and Parry-Jones 2007: 33). Between 1998 and 2006, more than $1300 \mathrm{t}$ of caviar were traded, $45 \%$ (or $491 \mathrm{t}$ ) of which was destined for the EU and $24 \%$ (313 t) for the US (Schneider 2012: 58-59). The EU is also one of the most important illegal markets with over $7 \mathrm{t}$ of illegal caviar seized by European law enforcement agencies between 2000 and 2007 (Traffic 2009: 2). In Europe, a wide range of caviar dealers, fashionable restaurants and Russian shops are being supplied with illegal caviar. ${ }^{29}$

The 1585 seizures of illegal caviar in the $\mathrm{EU}^{30}$ between 2001 and 2010 indicate that the size of the batches of contraband vary from a few hundred grams to hundreds of kilos, mainly originating from countries around the Caspian Sea. For example, an investigation revealed that two caviar businessmen smuggled at least $1.4 \mathrm{t}$ of caviar into the EU market in a single year (European Commission 2006). In total 10 tons of caviar were confiscated between 2001 and 2010 in the EU with a peak during the early 2000s, both in volume and incidents. $^{31}$ Over $40 \%$ of all seizures come from Russia $(N=579,41 \%){ }^{32}$ The annual value of legally exported caviar by the top exporter Russia is estimated to be between 40 and 100 million dollars, while the illegal Russian export of caviar is estimated to be no less than 250-400 million dollars (Pikitch et al. 2005: 241; Schneider 2012: 59-60). Other major countries of origin of illegal caviar are Azerbaijan $(N=190$, $13 \%)$ and Kazakhstan $(N=68,5 \%)$, with Ukraine $(N=199,14 \%)$ and Poland $(N=75$, $5 \%)$ as important transit countries. Germany $(N=832,53 \%)$, France $(N=293,19 \%)$ and Italy $(N=77,5 \%)$ appear to be major outlets in the EU for the illegal caviar trade (Fig. 1). For decades, these countries have been well-known for having substantial demand markets for legal and illegal caviar in the EU (Raymakers and Hoover 2002; Knapp et al. 2006; Traffic 2009).

On its way to Europe, caviar is hidden in special compartments in trucks and private cars or in personal hand luggage, with the complicity of airline employees (Knapp et al. 2006). Caviar is not only attractive to smuggle because it is valuable and available on the market, but also due to it is relatively easily concealable and removable (Moreto and Lemieux 2014). Smugglers of caviar can be divided into three types. The first type is the 'tourist', who buys caviar as a souvenir. Under this category are well-known artists and

\footnotetext{
${ }^{29}$ Personal communication with environmental crime expert at Europol, 26 September 2013, The Hague.

${ }^{30}$ The number of EU seizures can be found on the EU-TWIX database (the EU Trade in Wildlife Information eXchange), an instrument developed for international cooperation and information exchange between law enforcement agencies in the EU.

${ }^{31}$ The numbers of seizures in previous reports presented lower volumes (e.g. Engler and Parry-Jones 2007; Knap et al. 2006; Engler and Knapp 2008), because many seizures were recorded in the EU-TWIX database after these publications.

${ }^{32}$ Seizures of caviar in the United States between 2003 and 2012 indicate that more than $30 \%$ originates from Russia.
} 


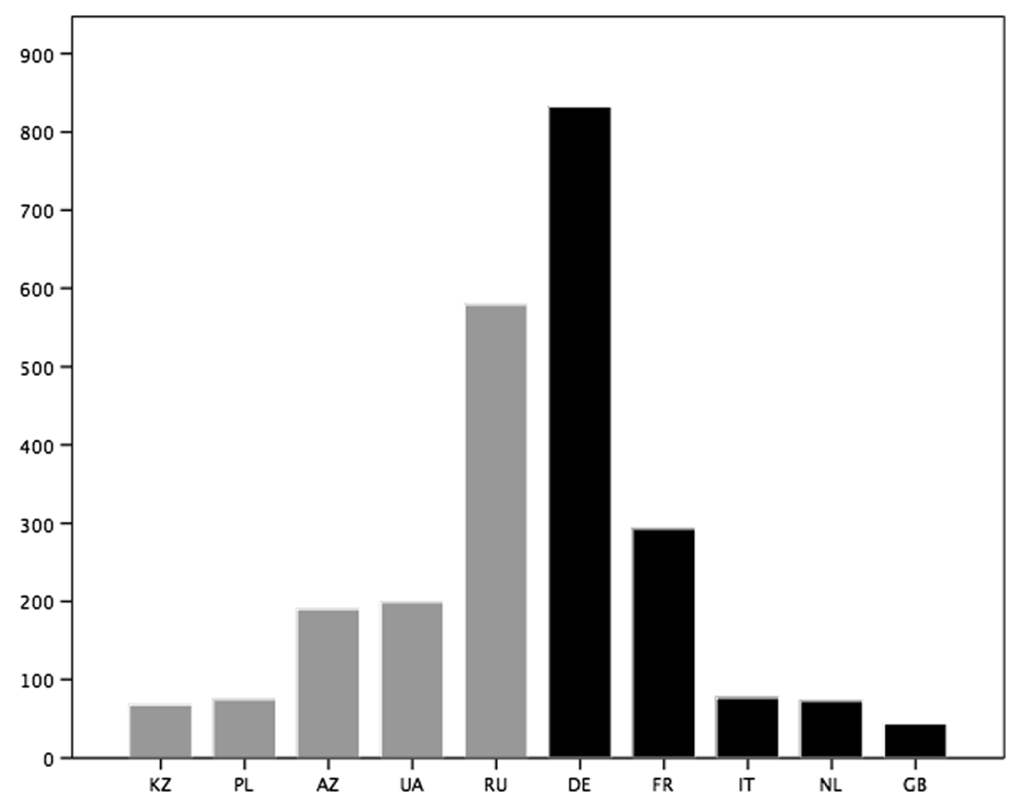

Fig. 1 Origin and destination countries based on EU confiscations (2001-2010). Source: EU-TWIX database, 2013. * Country codes: Kazakhstan (KZ), Poland (PL), Azerbaijan (AZ), Ukraine (UA), Russia (RU), Germany (DE), France (FR), Italy (IT), The Netherlands (NL), Great Britain (GB)

performers who buy their caviar at the markets in Moscow: "Rich people, movie stars and famous artists buy their caviar at the Dorogomilovsky market (...) This market is very famous and expensive (...) it is the best you can get in Moscow". ${ }^{33}$ They are usually unaware of the rules regarding the trade in caviar and try to bring back home more than $125 \mathrm{~g}$. The second type is the 'opportunist', mainly truck drivers or former residents, who try to sell several kilos of caviar in the country of destination to make some profit or to compensate for the fuel used. As described by an Iranian greengrocer in The Netherlands, "Besides the fact I really like caviar, especially from Iran, I sell it to friends and acquaintances to reduce the fuel costs". ${ }^{4}$ The third type is the 'well-organized smuggler' who is part of a criminal network and uses sophisticated methods. A smuggler interviewed highlighted: "We smuggle the caviar in these plastic buckets of $1 \mathrm{k}$ in refrigerated trucks (...) around $40 \mathrm{k}$ each time." ${ }^{35}$ Middlemen in Baku and Atyrau explained how they deploy airline employees to smuggle caviar out of the country. "No problem. This is a traditional smuggling method in which they [airline employees] hide caviar in their luggage. (...) Of course we have to bribe the customs officials." 36 The tins are then sold or repackaged and resold, but caviar is also being used as barter; for instance, a $500 \mathrm{~g}$ tin of caviar in exchange for a stolen western Mercedes (Neve et al. 2012).

\footnotetext{
${ }^{33}$ Personal communication with a caviar seller, 11 May 2015, Utrecht.

${ }^{34}$ Personal communication with a caviar seller, 25 March 2014, Moscow.

${ }^{35}$ Personal communication, 28 March 2014, Moscow.

${ }^{36}$ Personal communication, 27 September 2014, Baku.
} 
Based on seizures most illegal traders turned out to be Russian, French and Polish businessmen, while a remarkable number of facilitators (civil servants, lorry drivers and food merchants) are also involved in the illegal trade. A middleman in Moscow explained that it is useful "to have connections with Russians in countries abroad (...) to deliver the trade (...) my boss has such connections, those are often friends, acquaintances or Russians who he met during his business trips." Various respondents underlined that caviar is regularly smuggled by cars from the Caspian Sea to Moscow where the caviar is collected by middlemen and then smuggled through Belarus via Poland into the EU. The same middleman continued: "There is no border control between Russia and Belarus, we use this border and enter the EU by bribing Polish border officials." 37 According to Raymakers (2002: 21) Polish traders are involved in the illegal business, as Poland is traditionally used as a transit country to smuggle caviar from Russia to the EU. Hamburg in Germany is an important hub where caviar is laundered by corporations (Knapp et al. 2006; Neve et al. 2012). ${ }^{38}$ This smuggling route is confirmed by an illegal trader in the East of The Netherlands. He explained that he orders his caviar from a German trader who works together with a network of Russian entrepreneurs that deliver wild caviar by refrigerated trucks to Hamburg and Düsseldorf and then onwards to The Netherlands. ${ }^{39}$ According to an important middlemen in Baku substantial amounts of caviar are now smuggled from Russia and Azerbaijan through Georgia and Turkey into the EU, ${ }^{40}$ mostly by road, which is confirmed by confiscations (Fig. 2). ${ }^{41}$

Russian criminal groups also use counterstrategies in the European countries. In the UK, a raid in London by the National Criminal Intelligence Service (Operation Ribbon) associated illegal caviar trade with murder, extortion and corruption by Russian organized crime (Duffy 2010; Schneider 2012). In The Netherlands there are also indicators that the Russian mafia is involved in the caviar trade (AID 2009). In the early 2000s, when a large volume of illegal caviar from Russia was confiscated, Russians arrived at the national CITES office in Dordrecht to claim their caviar and threaten the employees. ${ }^{42}$ On another occasion, Russian criminals intimidated a law enforcer after caviar seizures by threatening him in front of his house (AID 2009). The inspector explained: "There was a lot of Russian caviar seized, nearly 10,000 k. (...) I was on the train home and got a call from my neighbour who said there were people sitting in a black Mercedes in front of my home and they were taking photographs. I asked her to give me the registration number and got in touch with my colleagues in the police. It turned out to be the same Russians who were involved in this illegal shipment". ${ }^{43}$ These examples serve to illustrate how illegal caviar

\footnotetext{
${ }^{37}$ Personal communication with a middleman, 25 March 2014, Moscow.

${ }^{38}$ In previous years the United Arab Emirates was also an important loophole of the illegal trade in caviar. Illegal caviar was laundered with falsified labels (Knapp et al. 2006). Organized crime groups in Dubai would be responsible for coordinating the illegal trade by forging documents and false declarations to obtain reexport certificates (Zabyelina 2013).

39 Personal communication, 01 August 2014, Venlo area.

${ }^{40}$ Personal communication, 27 September 2014, Baku.

${ }^{41}$ From 2000 until the beginning of 2014, from the 28 seizures with $1,615 \mathrm{~kg}$ of caviar, 16 confiscations $(1,272 \mathrm{~kg})$ were by truck or car, 7 by aircraft (114 kg), 1 by ship (4.5 kilo) and 7 outside border control (227 $\mathrm{kg})$.

42 Personal communication with a former CITES employee, 23 June 2015; inspector NVWA, 14 January 2014.

${ }^{43}$ Personal communication with an inspector of the NVWA, 14 January 2014.
} 


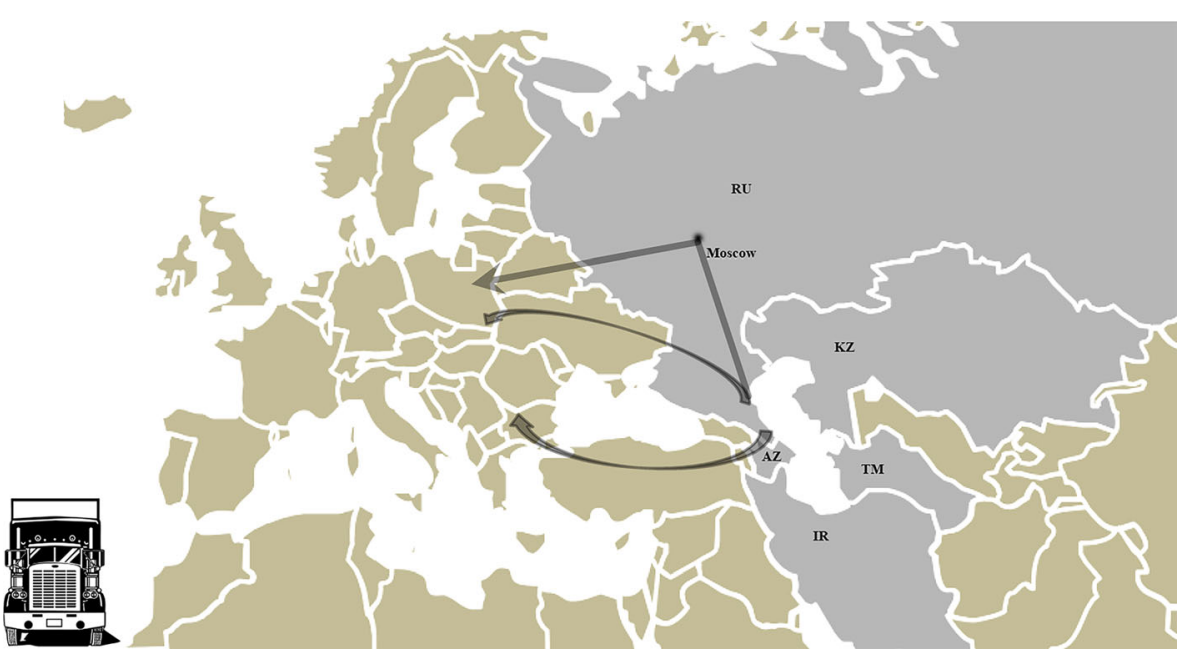

Fig. 2 Smuggling routes by road. Source: Based on interviews and confiscations in the EU

enters the European market and how criminal groups in Western Europe are active in smuggling and protecting their trade.

\section{Laundering and 'blackwashing' caviar}

Organized crime never operates in a social vacuum; it always interacts with its social environment, which provides fertile ground for their activities (Van de Bunt, Siegel, Zaitch, 2014). The 'caviar mafia' is another example of this intertwinement between the illegal and legal world. These criminal groups in the caviar trade are regularly embedded in legal enterprises that are used to shadow their illegal activities. According to different informants, in the post-Soviet period the official directors of the current fish farms in Russia were the 'big fishes' in the illegal trade in caviar. After the collapse of the Soviet Union in the early 1990s, the Russian mafia largely assumed the role of transferring economic assets into private hands. The mafia had taken over this responsibility of the state due to the inability of the state to provide order and the necessary services (Volkov 2002). The shadow economy in the mid and late 1990s constituted between 20 and $45 \%$ of the gross domestic product in Russia (Kosals 1998: 59).

In the post-communist period, legally registered companies use various methods to launder illegal caviar. The most common of which involve: the use of false or forged documents or labels, lids of illegal caviar tins and jars imitating well-known brands such as Russkaya Ikra, or bogus information about the producer, such as the nonexistent Russian Ministry of Fishery (Lawson 2002; Knapp et al. 2006). The trade in empty caviar tins and jars, lids and labels is flourishing. A middleman in Baku presented several lids of counterfeit caviar brands from Azerbaijan and Russia. He explained how, in this way, locally poached and produced caviar from Azerbaijan is sold as Russian caviar. ${ }^{44}$ Furthermore, official CITES certificates are often reused

\footnotetext{
${ }^{44}$ Personal communication, 27 September 2014, Baku.
} 
illegally: "The dealer orders a small batch of legal caviar, sends half of it back, and then uses his import license to sell illegal caviar." According to a 2009 police investigation named Platina, this is one of the most often used methods. ${ }^{45}$ Mislabelled caviar is also being detected in the EU (Knapp et al. 2006). Several authors mentioned illegal caviar from Russia smuggled through Dagestan and Azerbaijan to Iran where it is repacked together with legal Iranian caviar and send to destinations such as Europe (e.g. Zabyelina 2013). Another example is $1.6 \mathrm{t}$ of caviar from Kazakhstan that was confiscated in 2006 because the tins were originally from Astrakhan (Russia). The tins were exported as being Kazakh caviar as the quota in Russia was already full (AID 2009).

Although aquaculture is mentioned to be the solution for the decline in the sturgeon population, it could also be a risk to wild sturgeon (Kecse-Nagy 2011; Jahrl 2013; Sellar 2014). Sturgeon farms are expensive to run, require highly trained staff and it takes a long time before sturgeons actually spawn (Knapp et al. 2006; Zabyelina 2013). ${ }^{46}$ The involvement of aquaculture operations in 'laundering' wild-sourced caviar into 'cultivated' caviar is highlighted by several respondents. Sturgeon farms are cropping up all over the world, sometimes in unexpected places (Knapp et al. 2006; Sellar 2014), such as the Bulgarian stretch of the River Danube (Jahrl 2013) or the Caspian delta, where sturgeon is also found in the wild. ${ }^{47}$ Based on the author's observations, these possibilities are plausible: at two farms only a few sturgeons were spotted, while the companies claimed to produce annually more than half a ton of caviar. Moreover, one of the directors highlighted: "It is $100 \%$ possible that farms in Russia have such a laundering system". ${ }^{48}$ Furthermore, several commercial farms have documents to fish for sturgeons under the scientific quota. This is especially since it is undertaken by commercial fishing companies on behalf of the research facilities. These commercial fishing companies were more than willing to sign these agreements (Sellar 2014). An employee of a fish trade centre explained: "A famous caviar company in Atyrau has been involved, for a long time, in the trading of illegally caught sturgeon under the pretence of scientific purposes." 49 Statistical data covering several years after the ban demonstrates that $600 \mathrm{t}$ of caviar from sturgeon were fished out of the Caspian Sea for 'scientific purposes' (Zabyelina 2014). In comparison to the price of 'wild' caviar it still leaves the price of farming caviar non-competitive (Nikolaev et al. 2009). According to Levi and Reuter (2006) money laundering involves the transformation process of illegally obtained money into legitimate money. In the trade in caviar, illegally obtained caviar is mixed with legal caviar or transformed as being legal caviar.

A trend in the opposite direction has also been observed by several informants: "wild caviar is wanted' because it is rare and therefore special. The idea has taken hold that wild caviar, which is supposed to be 'pure and all-natural', is of a higher quality than caviar from cultured sturgeon. ${ }^{50}$ Moreover, wild caviar is illegal and therefore hard to get. The principle that 'what is banned or unavailable is always attractive' plays a major part here, but the consequence is that caviar from cultured sturgeon is now increasingly

\footnotetext{
$\overline{45}$ Personal communication with a police official, 26 February 2014, The Hague.

46 'The sturgeon has seen more years when it first spawns than many fish see in a lifetime' (Carey 2005).

${ }^{47}$ Personal observation of a sturgeon farm, 17 March, 2014, Ikryanoye; personal observation of a sturgeon farm, 24 September, 2014, Babayurt.

${ }^{48}$ Personal communication, 17 March, 2014, Ikryanoye.

${ }^{49}$ Personal communication, 20 March, 2014, Atyrau.

${ }^{50}$ Personal communication with caviar traders, 23 March, 2014, Astrakhan.
} 
often being sold as 'illegal' wild caviar, simply because it fetches a higher price. In keeping with this 'blackwashing', i.e. 'reverse laundering scheme', caviar dealers are encouraged to sell legal caviar as if it were an illegal product. This is a fairly new mechanism: legal caviar extracted from cultured sturgeons is being sold as illegal caviar. As a result of this, wild caviar retains its mystique and exclusivity as a 'banned' luxury product that is increasingly more difficult to come by. ${ }^{51}$

\section{Economic, social and environmental consequences}

The sturgeon, as one of the few species that survived the dinosaurs, is today one of the most endangered groups of animals on the Red List of endangered species because of overexploitation (IUCN 2010). However, to serve this delicacy at the table, one has to pay thousands of euros per kilo, because, similar to other endangered species, the economic value increases as the numbers of species decline (Courchamp et al. 2006; Van Uhm 2012, 2014). Due to the high value of caviar criminal networks are attracted, but also a circuit for imitation and 'long-life' caviar arises, whereby substances which are normally a danger to health are found. To preserve caviar for a longer period (around 10 months), prohibited bunion drugs were used. This is just one example; however, there is a wide variety of harmful activities as a result of sturgeon fisheries. Although not all of these forms of anthropocentric or environmental harms are criminalized by law, from a green criminological perspective the central question is not whether something is or is not punishable, but whether something is harmful (Wyatt 2013; White 2008: 33-35; White 2011). This is necessary to identify crimes or future crimes by studying inequalities among people, ecosystems and wildlife (Van Uhm 2015: 580).

Due to the excessive and commercial sturgeon fishing, a ban on fishing for sturgeon in the Caspian Sea is active. This criminalization of the fishing for sturgeon can lead to 'protest fishing', where local fishermen continue to fish because they believe that it is their right to do so. These fishermen are being deprived and experience social harm because this source of income has disappeared due to overexploitation (Nurse 2015). Especially for Dagestani fishermen the ban can have far-reaching consequences, since entire generations live of sturgeon fishing and caviar sales. Moreover, it is not exceptional that the authorities respond in a 'military' fashion - inspectors in the Caspian Sea area are generally armed with automatic rifles - and subsequently fishermen militarize themselves to gain access to the fish resources. This results in armed conflicts and overexploitation (Hauck 2007: 272-274). The ban may even lead to an escalation of tension between territories, such as Dagestan and Kazakhstan (Raymakers 2002).

Furthermore, from an ecocentric harm perspective the massive poaching of sturgeon puts pressure on the marine ecosystem. All species interact in complex ways and the survival of indigenous species such as the sturgeon in the Caspian Sea is an indicator of a healthy ecosystem. If a species decreases the balance in the ecosystem may be adversely affected (Wilson and Kellert 1993). In the Caspian Sea, one of the world's most precious and unique ecosystems, the extinction of the sturgeon can lead to the disappearance of species and even the collapse of an ecosystem. Especially since

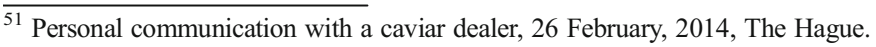


certain sturgeon species are considered to be a keystone species (Rossum 2013; US Environmental Protection Agency 2009). Thus the caviar trade is not only harmful to humans, for example with regard to food safety and natural resources disappear for local fishermen, but also harmful to the sturgeon as a species (biodiversity/animal welfare) and its natural environment (the ecosystem).

\section{Discussion and conclusion}

From a food of the poor to a luxury product - caviar has a long and rich history. The value of caviar was historically determined in the context of changing social and political relationships and, in the last century, also by rapid ecological changes. The scarcity of 'real' (wild) caviar has offered a unique opportunity for organized crime to earn millions of euros from illegal fishing, smuggling and trafficking in various countries. This study has aimed to shed light on the contextual factors, criminal networks and consequences of the caviar trade. Moreover, the study provided the opportunity to analyse the unique, ground-level perspectives of the actors involved in the trade. Given their first-hand information, this made it possible to obtain an in-depth understanding of the caviar trade.

In the current study, we identified several criminogenic factors that make the illegal caviar trade extremely attractive for organized crime, such as scarcity, the extremely high prices paid for caviar, social instability and corruption in the countries of origin, relative less control and loopholes in regulation. This study highlights that these criminal networks manifest themselves at all levels of the trade: from the poaching areas where organized criminal groups cooperate with law enforcers and possess topnotch equipment, such as GPS, expensive boats and helicopters, to major smuggling operations in the hands of sophisticated criminal networks that cooperate with local officials. The poor living conditions of poaching towns, sometimes only accessible by boat, were observed and highlighted by informants. According to Passas (2000) these forms of crime would be a normal response to cultural expectations in society as poor people would commit crimes to fight injustice. Criminal entrepreneurs benefit from these socio-economic asymmetries between origin and destination countries (Passas 2000 , 2002). These remote, relatively poor areas, such as Dagestan, where the government has not succeeded in using the effective monopoly of violence, are in particularly vulnerable to the involvement of organized crime groups (Bovenkerk 2001). The Caspian region is not an exception, however, the criminal networks are also active outside the Caspian countries, in West European countries. Several informants explained how Russian criminal groups are involved in smuggling and protecting their trade by counterstrategies in Europe as one of the major outlets of illegal caviar.

Furthermore, this study addressed the activities of criminal networks that control the illegal trade in caviar, taking advantage of its strong ties with the upperworld. Typical characteristics of organized crime such as a high degree of organisation, corruption, maintaining their position by violence and the entwined legal-illegal interface are all present in this case study (Paoli 2014; Kleemans 2014; Van de Bunt, Siegel and Zaitch 2014). The caviar mafia operates not in a social vacuum, but is embedded in the legal business whereby the infrastructure of farms and legitimate companies are used to launder illegal caviar. The informants underlined 
the involvement of aquaculture operations in laundering illegal wild-sourced caviar into cultivated caviar, but also caviar dealers who are 'blackwashing' caviar from cultured sturgeon as 'illegal' wild caviar that fetches a higher price. It is plausible that organized crime took over the control of former state companies and controlled local councils, government agencies and bodies that were arms of the state (e.g. Volkov 2002). This is partly confirmed by informants in these source countries who highlighted their symbiotic relations with officials by paying taxes. However, it was not always clear who belonged to the caviar mafia. The fishermen reported that the police and dealers were the caviar mafia, while the traders referred to the poachers and the police. Many locals used the term to consider the entire business in the hands of the Russian mafia. The illegal market is certainly well organized, as is illustrated by its participants who arrange for sales channels, transport, and bribes to be paid along the way to traffic police and customs officers.

The economic, social and environmental consequences are considerable. In the trade in wildlife many harmful activities, such as the global destruction of the environment and violent activities regarding animals, are not criminalized (South 1998; White 2008, 2011). Generally, natural resources are exploited without any regulation (Wyatt 2013; Sollund and Maher 2015). Due to the excessive and commercial sturgeon poaching, a source of income has disappeared for local communities, conflicts have emerged and the unique Caspian ecosystem - including its species - is being damaged. Although irreparable ecological harm does not outweigh the short-term gain from the well-organized criminal organisations, corrupt officials and politicians, the illegal trade continues. Declining numbers of wild sturgeon and sky-high prices paid for original wild caviar place the future of this prehistoric fish at risk.

Compliance with ethical standards All procedures performed in studies involving human participants were in accordance with the ethical standards of the institutional and/or national research committee and with the 1964 Helsinki declaration and its later amendments or comparable ethical standards.

Conflict of interest The authors declare that they have no conflict of interest.

Informed consent Informed consent was obtained from all individual participants included in the study.

Open Access This article is distributed under the terms of the Creative Commons Attribution 4.0 International License (http://creativecommons.org/licenses/by/4.0/), which permits unrestricted use, distribution, and reproduction in any medium, provided you give appropriate credit to the original author(s) and the source, provide a link to the Creative Commons license, and indicate if changes were made.

\section{References}

AID (2009) Tactische Analyse Kaviaar. Dienst Opsporing Informatie en Analyse. Ministerie van Landbouw, Natuur en Voedselkwaliteit, The Hague

Birstein VJ, Bemis WE, Waldman JR (1997) The threatened status of acipenseriform species. A summary. In: Birstein VJ, Bemis WE and Waldman JR. Sturgeon Biodiversity and Conservation. Springer, New York

Bovenkerk F (2001) Misdaadprofielen. Meulenhoff, Amsterdam

Bronzi P, Rosenthal H (2014) Present and future sturgeon and caviar production and marketing: a global market overview. J Appl Ichthyol 30(6):1536-1546 
Carey RA (2005) The Philosopher Fish: Sturgeon, Caviar, and the Geography of Desire. Counterpoint Press, Berkeley

Charmaz K (2006) Constructing grounded theory: a practical guide through qualitative analysis. Sage Publications, Thousand Oaks

Cheloukhine S, Haberfeld MR (2011) Russian organized corruption networks and their international trajectories. Springer, New York

Clarke RV (1983) Situational crime prevention: its theoretical basis and practical scope. Crime Justice: An Annu Rev Res 4:225-256

Coleman C, Moynihan J (1996) Understanding crime data: haunted by the dark figure. Open University Press, Buckingham

Courchamp F, Angulo E, Rivalan P, Hall RJ, Signoret L, Bull L, Meinard Y (2006) Rarity value and species extinction: the anthropogenic allee effect. PLoS Biol 4(12)

Davies P, Francis P, Jupp V (2011) Doing criminological research. Sage Publications, Thousand Oaks

De Meulenaer T, Raymakers C (1996) Sturgeons of the Caspian sea and in the international trade in caviar. Traffic International, Brussels

DeWalt KM, DeWalt BR (2011) Participant observation: a guide for fieldworks. AltaMira Press, Lanham, MD

Duffy R (2010) Nature crime: how we're getting conservation wrong. Yale University Press, New Haven

Engler M, Parry-Jones R (2007) Opportunity or threat: the role of the European Union in global wildlife trade. Traffic Europe, Brussels

Engler M, Knapp A (2008) Briefing on the Evolution of the Caviar Trade and Range State Implementation of Resolution Conf. 12.7 (Rev. CoP14). A Traffic Europe Report for the European Commission. Traffic Europe, Brussels

European Commission (2006) Study on the enforcement of the EU wildlife trade regulations in the EU-25. European Commission, Brussels

European Commission (2010) Wildlife trade regulations in the European Union. An Introduction to CITES and its Implementation in the European Union. Publications Office of the European Union, Luxembourg

Glenny M (2008) McMaffia: crime without frontiers. Bodley Head, London

Goodman LA (1961) Snowball sampling. Ann Math Stat 32(1):148-170

Gordon M (2003) Such stuff as dreams are made on: the story of caviar from prehistory to the present. In: Food and Drug Law. An Electronic Book of Student Papers, Cambridge

Hauck M (2007) Non-compliance in small-scale fisheries: a threat to security? In: Beirne P, South N (eds) Issues in green criminology: confronting harms against environments, humanity and other animals. Willan Publishing, Devon

Hillyard P, Pantazis C, Tombs S, Gordon D (eds) (2004) Beyond criminology. Taking Harm Seriously. Pluto Press, London

International Union for Conservation of Nature (2010) Sturgeon more critically endangered than any other group of species. IUCN, Gland

Jahrl J (2013) Illegal caviar trade in Bulgaria and Romania. Results of a market survey on trade in caviar from sturgeons (Acipenseridae). WWF Austria and TRAFFIC, Vienna

Kecse-Nagy K (2011) Trade in sturgeon caviar in Bulgaria and Romania overview of reported trade in caviar, 1998-2008. A traffic report for WWF Austria, Budapest

Kleemans E (2014) Theoretical perspective on organized crime. In: Paoli L (ed) The oxford handbook of organized crime. Oxford University Press, Oxford

Knapp A, Kitschke C, von Meibom S (eds) (2006) Proceedings of the international sturgeon enforcement workshop to combat illegal trade in caviar. Prepared by TRAFFIC Europe for the European Commission, Brussels

Kosals L (1998) Tenevaya ekonomika Kak osobennost rossiiskogo kapitalisma (shadow economy as a feature of Russian capilaism). Vopr Ekon 10:59-80

Lawson T (2002) Traded towards extinction? The role of the UK in wildlife trade. A WWF Report, Surrey, UK

Levi M, Reuter P (2006) Money laundering. Crime Justice. doi:10.1086/501508

Liddick DR (2011) Crimes against nature. Illegal industries and the global environment. Praeger, Santa Barbara

Maltsev SA (2009) Conservation of the sturgeon fish in lower Volga. In: Carmona R, Domezain A, García Gallego M, Hernando JA, Rodríguez F, Ruiz-Rejón M (eds) Biology, conservation and sustainable development of sturgeons. Springer, Netherlands, Dordrecht

Marcus GE (1995) Ethnography in/of the world system: the emergence of multi-sited ethnography. Annu Rev Anthropol 24:95-117

Mintz SW (1985) Sweetness and power. Penguin Books, New York 
Moreto WD, Lemieux AM (2014) From CRAVED to CAPTURED: introducing a product-based framework to examine illegal wildlife markets. Eur J Crim Policy Res 21(3):303-320

Nellemann C, Henriksen R, Raxter P, Ash N, Mrema E (eds) (2014) The environmental crime crisis - threats to sustainable development from illegal exploitation and trade in wildlife and forest resources. A UNEP Rapid Response Assessment. United Nations Environment Programme and GRID-Arendal. Birkeland trykkeri AS, Norway

Neve R, Liezen J, Nieuwdorp A, Redder K, van der Zon G (2012) Milieucriminaliteit in Nederland. Een inventarisatie voor het Nationaal dreigingsbeeld 2012. Deel 2 versterkingsprogramma milieucriminaliteit/ NDB 2012. IPOL-KLPD, Zoetermeer

Nikolaev AI, Andrianov DP, Burtsev IA, Kopylenko LR, Kotenev BN, Safronov AS (2009) International trade in caviar and business perspectives in Russia. In: Biology, Conservation and Sustainable Development of Sturgeons. Springer, New York

Nurse A (2015) Policing wildlife. Perspectives on the enforcement of wildlife legislation. Palgrave Macmillan, London

Oldfield S (2003) The trade in wildlife. Regulation for conservation, Earthscan, London

Paoli L (2014) Introduction. In: Paoli L (ed) The oxford handbook of organized crime. Oxford University Press, Oxford

Passas N (2000) Global anomie, dysnomie, and economic crime: hidden consequences of neoliberalism and globalization in Russia and around the world. Soc Justice 27(2):16-44

Passas N (2002) Cross-border crime and the interface between legal and illegal actors. Upperworld and underworld in cross-border crime. Wolf Legal Publishers, Nijmegen

Perry-Jones R, Engler M (2007) Opportunity or threat. The role of the European Union in the global wildlife trade. Traffic Europe, Brussels

Petrossian GA, Clarke RV (2014) Explaining and controlling illegal commercial fishing an application of the CRAVED theft model. Br J Criminol 54(1):73-90

Pikitch EK, Doukakis, P, Lauck, L, Chakrabarty, P, Erickson, DL (2005) Status, trends and management of sturgeon and paddlefish fisheries. In: Fish and Fisheries, Wiley, New York

Pires SF, Moreto WD (2011) Preventing wildlife crimes: solutions that can overcome the 'tragedy of the commons'. Eur J Crim Policy Res 17(2):101-123

Raymakers C (2002) Study on the social and economic aspects of illegal fishing in the Caspian sea. Traffic Europe, Brussels

Raymakers C, Hoover C (2002) Acipenseriformes: CITES implementation from range states to consumer countries. J Appl Ichthyol 18:629-638

Rossum M (2013) Written Testimony Regarding H.R. 1900, Natural Gas Pipeline Permitting Reform Act Submitted by Maya K. van Rossum, the Delaware Riverkeeper to the House of Representatives Committee on Energy and Commerce, Subcommittee on Energy and Power July 9, 2013. Delware riverkeeper network, Washington

Ruban GI, Khodorevskaya RP (2010) Caspian sea sturgeon fishery. A Historic oVerview J Appl Ichthyol 27: 199-208

Saffron I (2002) Caviar. The strange history and uncertain future of the World's Most Coveted Delicacy. Broadway Books, New York

Schneider JL (2012) Sold into extinction. The global trade in endangered species. Praeger, Santa Barbara

Sellar JM (2014) The UN'S lone ranger. Combating International Wildlife Crime. Whittles Publishing, Caithness

Shadrina E (2007) The great Caspian caviar game. Security Index A Russian Journal on International Security 13:55-78

Siegel D (2005) Russische bizniz. Meulenhoff, Amsterdam

Siegel D (2009) The mazzel ritual. Springer, New York

Simis KM (1982) USSR: the corrupt society. The secret world of soviet capitalism. Simon and Schuster, New York

Simmel G (1978) The philosophy of money. Routledge, London

Sollund R (2013) Animal trafficking and trade: abuse and species injustice. In: Westerhuis DS, Walters R, Wyatt $\mathrm{T}$ (eds) Emerging issues in green criminology: exploring power, justice and harm. Palgrave Macmillan, Basingstoke

Sollund R, Maher J (2015) The Illegal Wildlife Trade. A Case Study Report on the Illegal Wildlife Trade in the United Kingdom, Norway, Colombia and Brazil. University of Oslo and University of South Wales, Oslo \& Wales

South N (1998) A green field for criminology: a proposal for a perspective. Theor Criminol 2(2):211-233

Spradley JP (1980) Participant observation. Wadsworth, Belmont 
Stiles D, Redmond I, Cress D, Nellemann C, Formo RK (eds) (2013) Stolen apes - the illicit trade in chimpanzees, gorillas, bonobos and orangutans. A Rapid Response Assessment. United Nations Environment Programme, GRID-Arendal

Taylor S (1997) The historical development of the caviar trade and the caviar industry. Sturgeon stocks and caviar trade workshop. IUCN, Switzerland

Traffic (2009) Fact sheet. Black Gold. The Caviar Trade in Western Europe. Traffic Europe, Brussels.

Traffic (2014) The scale of the EU's wildlife trade. In: Briefing Paper. Traffic Europe, Brussels

US Environmental Protection Agency (2009) Detroit River-Western Lake Erie Basin Indicator Project

Vaisman A (1997) Sturgeon catch and trade in the Russian part of the Caspian sea. Traffic Europe, Brussels

Van de Bunt H, Siegel D, Zaitch D (2014) The social embeddedness of organized crime. In: Paoli L (ed) The oxford handbook of organized crime. Oxford University Press, Oxford

Van Uhm DP (2012) De illegale Handel in beschermde diersoorten. Justitiële Verkenningen 38:91-100

Van Uhm DP (2014) Criminaliteit en traditionele Chinese medicijnen. Proces 93(2):130-143

Van Uhm DP (2015) Towards moral principles regarding non-human animals: a green criminological perspective. In: Vervaele JAE et al. (eds) Overarching views of crime and deviancy. Rethinking the legacy of the Utrecht School. Eleven International Publishing, The Hague

Van Uhm DP (2016) Illegal trade in wildlife and harms to the world. In: Spapens ACM, White R, Huisman W (eds) Environmental crime in transnational context. Ashgate Publishing, Farnham

Varese F (2001) The Russian mafia. Private protection in a new market economy. Oxford University Press, Oxford

Volkov V (2002) Violent entrepreneurs. The use of force in the making of Russian capitalism. Cornell University Press, Ithaca and London

White R (2008) Crimes against nature. Environmental criminology and ecological justice. Willan Publishing, Cullompton

White R (2011) Transnational environmental crime. Toward an eco-global criminology, Routledge

Wilson EO, Kellert SR (1993) The biophilia hypothesis. Island Press, Washington

Wyatt T (2013) Wildlife trafficking. A deconstruction of the crime, the victims, and the offenders. Palgrave Macmillan, London

Wyler LS, Sheikh PA (2013) International illegal trade in wildlife. Threats and US policy. Library of Congress Washington DC Congressional Research Service, Washington.

Zabyelina YG (2013) The state and transnational organized crime: a case study analysis of criminal opportunities in the Russian Federation and the United States. Doctoral dissertation, University of Trento

Zabyelina YG (2014) The "fishy" business: a qualitative analysis of the illicit market in black caviar. Trends in Organized Crime. doi:10.1007/s12117-014-9214-z

Zaitch D, Mortelmans D, Decorte T (2009) Participerende observatie in de criminologie. In: Decorte T, Zaitch $\mathrm{D}$ (eds) Kwalitatieve methoden en technieken in de criminologie. Leuven, Acco, pp. 261-314 